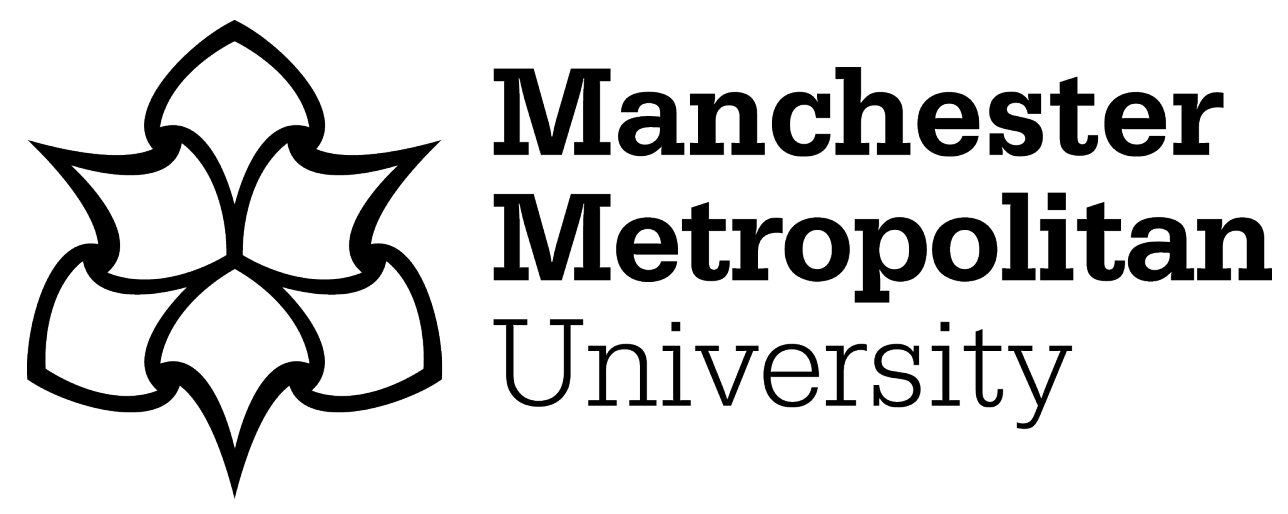

Simpson, K (2019) European Union crises and Irish public opinion: continuity and change in patterns of support. Irish Political Studies, 34 (4). pp. 507529. ISSN 0790-7184

Downloaded from: https://e-space.mmu.ac.uk/625057/

Version: Accepted Version

Publisher: Taylor \& Francis (Routledge)

DOI: https://doi.org/10.1080/07907184.2019.1647171

Please cite the published version 


\title{
European Union Crises and Irish Public Opinion: Continuity and Change in Patterns of Support
}

\begin{abstract}
Individuals in Ireland are one of the most enthusiastic supporters of European integration since accession to the European Union (EU) in 1973 often coined as 'good Europeans with a pro-integrationist attitude'. The economic and financial crisis is regarded as a turning point in Ireland's relationship with the EU as a result of the economic downturn and the widening of economic disparities individuals have experienced. Meanwhile, Brexit poses significant and specific challenges to Ireland and has the capacity to impact Irish attitudes towards the EU. Using a combination of Standard Eurobarometer data from $2007-2018$ and a variety of opinion polling data, this paper will examine how the economic crisis and Brexit have shaped Irish attitudes towards the EU.
\end{abstract}

KEY WORDS: Ireland, Public Opinion, Economic \& Financial Crisis, Brexit, Irexit, Support for the European Union 


\section{INTRODUCTION}

Since the economic and financial crisis trends in public opinion suggest that citizens of the European Union (EU) are becoming more critical of the EU project as individuals perceive themselves to be at heightened risk of economic insecurity as a consequence of economic problems in their EU member state and the EU as a whole. Nevertheless, recent research has demonstrated that while individuals in Ireland were disappointed and indeed angered by the performance of the EU during the economic crisis, in particular among those who experienced increased economic instability, overall individuals in Ireland remain enthusiastic supporters of the EU project (Simpson, 2018a and 2018b). Brexit meanwhile poses another period of instability - both economically and politically - for individuals in Ireland specifically for bilateral relations with the UK on economic and trading matters and the pursuit of Irish objectives as an EU member state.

This paper comprehensively examines Irish attitudes towards the EU using a combination of Standard Eurobarometer data from 2007 - 2018 and opinion polling data from both Red C and Ireland Thinks analysing variables such as whether membership of the EU is a good thing, whether Ireland has benefited from EU membership, attitudes towards an Irish exit of the EU as well as the most important issue individuals in Ireland are facing. The paper shows firstly the importance individuals place on both the economic crisis and the Brexit crisis and secondly how this shapes Irish attitudes towards the EU. The results from both the Standard Eurobarometer data and opinion polling data show that mass public opinion support for the EU in Ireland remains robust in spite of these two crises. While the EU continues to be regarded as an economic project in Ireland what is evident in this analysis is a shift towards more policy specific issues. 


\section{IRISH PUBLIC OPINION TOWARDS THE EU}

There are a vast variety of data dating from the early 1970s which can be examined in order to assess Irish attitudes towards the EU ranging from large-N surveys and opinion polls, EU-related referendum results and European Parliament Election results. The focus of this paper is to examine mass public opinion towards the EU from the economic and financial crisis to the Brexit crisis, therefore the analysis here will focus predominantly on Standard Eurobarometer large-N survey data as well as opinion polls pertaining to Brexit as well as some tentative analysis on EU-related referendum results. The paper will not examine results of the 2009 and 2014 European Parliament elections in Ireland as this has been covered extensively elsewhere (Quinlan, 2010; Okolikj \& Quinlan 2015 \& Quinlan \& Okolikj, 2016).

Ireland is often regarded as one of the most enthusiastic supporters of European integration since its accession to the EU in 1973 as they are often considered as 'good Europeans' with a pro-integrationist attitude (Sinnott 1995, Sinnott 2002, Gilland 2002; Sinnott 2005; Kennedy \& Sinnott 2006; Kennedy \& Sinnott 2007; Lyons 2008; Adshead \& Tonge 2009). However, the reality of Irish public opinion is more nuanced: support for the EU in Ireland is not a single entity, but a complex set of opinions determined by a variety of factors. Research has shown that since the 1990's knowledge about the EU amongst the Irish public is low (Gary, Marsh \& Sinnott 2005; Holmes 2005; Kennedy \& Sinnott 2006; Kennedy \& Sinnott 2007; Laffan \& O’Mahony 2008 pp. 128) with individuals in Ireland more likely to refer to the economic aspects of the EU, such as the freedom of movement, the Euro and economic prosperity. This 'knowledge deficit' is perhaps not surprising as for the first twenty years of EU membership Ireland's self-perception of its status within the EU was that of a small, poor, peripheral member state. In their examination of the nuances of Irish public opinion toward the EU Kennedy and Sinnott (2007) find that Irish individuals' knowledge of the EU does not affect the relationship between opinion of EU support and evaluations of domestic and 
European institutions. Therefore, the EU project in Ireland is not one which can be encapsulated by a single overarching judgment, but by many different facets.

The pro-EU status of the Irish began to be challenged in the 2000s when Ireland's economic boom led the Irish government into conflict with the EU over its management of the Irish economy. The Irish government was criticized for its refusal to dampen the successful Celtic Tiger economy and for its substantial tax concessions for foreign investors which were (and still are) regarded by the European Commission as breaking the spirit if not law of the European Single Market. However, individuals in Ireland tend to focus on national or intergovernmental aspects of EU membership and representation rather than on the policymaking aspects of EU institutions which produce legislation that has an effect across all EU member states. Therefore, there remains a proportion of the population who oppose further 'sharing of sovereignty' and are concerned about the impact Ireland's involvement in the EU is having on Irish identity, values and culture. These nuances and the multifaceted nature of Irish public opinion towards the EU were borne out in the rejection of the Nice Treaty in May 2001 and the Lisbon Treaty in June 2008.

\section{The Complexity of EU Referendums in Ireland}

The Republic of Ireland, as a relatively contemporary addition to the international community and as a consequence of its strongly nationalist political culture, encouraged the insertion in its 1937 constitution of an unambiguous declaration of sovereignty (Coakley, 2005). The rationale behind the 1973 referendum on accession to the then European Economic Community (EEC) was necessary in order to correct the conflict that the obligations of membership would cause for the Irish constitution; Bunreacht na hEireann. Under obligations of EEC membership, and alongside the supremacy of European law, legislative authority would no longer be solely invested in the Oireachtas (legislature of Ireland) and the European Court 
of Justice (ECJ) would be superior to the Irish Supreme Court. On this basis, a decision was made to introduce a catch-all amendment (Article 29.4.3) allowing Ireland to join the EEC following a referendum (O’Mahony, 2009). In 1986 however the approval of the Single European Act (SEA) led to Crotty vs An Taoiseach- a landmark decision by the Irish Supreme Court which found that Ireland could not ratify the SEA unless the Irish constitution was amended to permit ratification. The decision was taken to confine the 1987 referendum to the specific issue - i.e. the ratification of the SEA rather than introducing an all-encompassing amendment that would make all future EU-related referendums unnecessary. As a consequence, since 1987, any further integration or extension of EU powers requires a fresh referendum in Ireland.

Subsequently, between 1973 and 2012, Irish governments have held nine European referendum campaigns with two broad characteristics emerging from each campaign. Firstly, turnout in EU-related referendums is generally lower than at Irish general elections with the lowest turnout being $34.79 \%$ in the first referendum on the Nice Treaty in 2001 (see Table 1). Secondly, EU-related treaties (with the exception of the Accession Treaty in 1973) have gained broad support across the political establishment including the mainstream political parties, trade unions and business organizations. Political parties such as Sinn Fein and the Green Party as well as non-party political and civil society groups have all opposed EU-related referendums. Up until the first referendum on the Treaty of Nice in 2001, successive Irish governments and pro-European campaigners pointed to the benefits EU membership had brought to Ireland in terms of direct financial transfers and increased opportunities for Irish workers and Irish industry. Pro-European groups and political parties in Ireland have consistently relied upon the permissive consensus and the fact that individuals in Ireland appreciated the considerable benefits Ireland derived from EU membership thus little effort was made to explain the issues at stake for the Irish electorate. 
The rejection of the Nice Treaty in 2001 and the Lisbon Treaty in 2008 highlighted the potential emergence of a new popular scepticism towards the EU in so far as it concerns Irish interests and deeper European integration in Ireland. At Nice 1, consensus across the Irish political establishment was in evidence. The smaller political parties of Sinn Fein, the Green Party and the Socialist Workers' party all campaigned against the Nice Treaty. While the Yes campaign was promoted to the electorate as being in Ireland's best interests as it would facilitate the 'Big Bang' enlargement of the EU in 2004 from fifteen to twenty-five member states thereby providing Irish industry access to enlarged European Single market. However, with a general election in 2002, political parties advocating a Yes vote were reluctant to spend money campaigning on an EU referendum and thus the message proposed to the public was unclear (O'Mahony 2009). In contrast, the No campaign including groups such as 'No to Nice', PANA $^{1}$ ran a highly committed and visible campaign under the slogan "If You Don't Know, Vote No" placing the knowledge deficit inherent within the mass public of Ireland front and centre of the campaign subsequently leading to the rejection of the Nice Treaty by $54 \%$ of the electorate (with the lowest ever turnout in an EU referendum of $35 \%$ see Table 1).

By Nice 2 in 2002, those advocating a Yes vote did not withdraw from the referendum campaign arena and a re-engaged political elite were joined by a wide variety of civil society groups organised under the umbrella organisation "Alliance for Europe" and a National Forum on Europe was established to communicate the key issues to the wider public in advance of the second Nice referendum. These initiatives were directly employed to correct the knowledge gap displayed among the public in Nice 1 - and the approaches were successful as $63 \%$ of the Irish electorate voted to ratify the Nice Treaty in October 2002 (see Table 1).

\footnotetext{
${ }^{1}$ Peace and Neutrality Alliance
} 
For Lisbon 1, the political elite retreated from the referendum campaign once again through a combination of accident and design - the then Taoiseach Bertie Ahern was preoccupied by a judicial enquiry and accompanied with public concern his position came under scrutiny. Confusion also existed as to when the referendum would take place given the procrastination on naming a date (Laffan \& O’Mahony 2008, pp. 116). Between April (announcement of Ahern's intention to resign) and May 2008 (the appointment of Brian Cowen as Taoiseach) a political vacuum emerged which was effectively occupied by No to Lisbon campaigners such as Libertas, COIR and the People's Movement (Fitzgibbon, 2012). Those advocating a Yes vote to the Lisbon Treaty were aware of the difficulties as it does not contain one grand idea (Moravcsik, 2008) - as an amending treaty its focus is on incremental reforms to EU decision-making and policy making procedures. Given that Irish public opinion tends to focus on economic aspects of the EU, such as the freedom of movement, the Euro and economic prosperity, there was concern of how the knowledge deficit would play a role in Lisbon 1. This was evident in opinion polls in the lead up to the referendum with a TNS/MBRI poll for The Irish Times in November 2007 highlighting that only $25 \%$ of individuals surveyed intended to vote Yes, $13 \%$ intended to vote No while $62 \%$ said they did not know or had no opinion (TNS/MBRI, 2007). The Yes campaign focused on a narrative of trust to rally the electorate using slogans such as "Good for Ireland, Good for Europe" and "Europe Let's Be at the Heart of It". However, given the early foothold of the No campaign, the Yes campaign spent much of its time refuting No campaign arguments as well as misinformation and as such the electorate did not vote to ratify the Lisbon Treaty in 2008 (see Table 1).

By Lisbon 2, the Yes campaign argued that the EU had listened to the concerns of the Irish people and responded with legal guarantees which pertained to issues raised by the No campaign. With the onset of the economic and financial crisis, the Yes campaign argued that full involvement in the EU was essential for the Irish economic recovery. Research by Sinnott 
et al (2010) confirms that this strategy by the Yes campaign was a success as individuals voted Yes in Lisbon 2 as they believed it would lead to an improvement in Ireland's economic prospects. Quinlan (2012) also supports this finding and argues that a switch from No to Yes in the Lisbon Treaty referendums is explained not only by the changed economic circumstances of Ireland but also by guarantees secured by the Irish government on the issues of corporation tax, an EU Commissioner as well as a more informed electorate - thus closing the knowledge deficit evident in Lisbon 1.

Overall, the emergence of referendums as key forums for debate about the EU in Ireland has resulted in a much greater degree of polarisation of opinions with Gary, Marsh and Sinnott (2005) and Glencross and Trechsel (2011) demonstrating that voting in EU-related referendums typically distinguish between 'second-order' effects and the impact of 'substantive 'issues'. As Garry (2013) points out, findings with regards to both 'second-order' and 'issue-voting' approaches are of significant theoretical importance for the understanding of individual-level political behaviour and normative evaluations of the practicality of using the mechanism of referendums to ratify EU treaties. The 'second order' effects approach infers that the central determinant of vote choice in EU-related referendums is an EU member states national party politics and that voters often use referendums in order to express their discontent or satisfaction with the incumbent government as well as determining their vote as a result of party cues with people voting in accordance with their political party affiliation. While according to the 'issue voting' approach, voting in EU related referendums is driven by individuals' EU-related concerns i.e. people decide to support, or not support, a treaty based on the merits of the European project and the specific elements that particular treaty poses to them. 


\section{The Economic \& Financial Crisis - A Turning Point}

The economic and financial crisis can be regarded as a decisive moment in Ireland's relationship with the EU as a result of the economic downturn and a widening of economic disparities individuals have experienced. However, despite this turning point Irish attitudes towards the EU have remained consistently positive (Simpson, 2018a and 2018b). This can be seen in the variety of data sources pertaining to mass public opinion towards the EU in Ireland; in particular; EU-related referendum results and large-n surveys and opinion polls,

Beginning with EU-related referendum results, it is evident from the analysis above that when the Irish electorate voted 'No' to the Nice Treaty in May 2001 and the Lisbon Treaty in June 2008 both the domestic political and economic context played a vital role highlighting elements of the 'second order' and 'issue voting' approaches. In the first Nice Treaty referendum three key issues were at stake: sovereignty, neutrality and EU enlargement emphasising 'issue voting' by the electorate ${ }^{2}$. In the first referendum on the Lisbon Treaty 'second-order' factors can be cast aside as satisfaction with the Irish government declined significantly between Lisbon 1 and Lisbon 2 . The change in the political context from the first Lisbon Treaty referendum in June 2008 to the second Lisbon Treaty referendum in October 2009 was a result of the Irish Government's attempts to address concerns highlighted by the 'No' campaign on issues in relation to military neutrality, the corporation tax rate, the belief that abortion services would be widely available, a weakening of workers' rights and a reduction in Irish influence at the EU-level due to the loss of a permanent Irish EU Commissioner ${ }^{3}$.

However, it was perhaps the change in economic context from Lisbon 1 to Lisbon 2 which was most dramatic as Ireland plunged into recession after the rejection of the first

\footnotetext{
${ }^{2}$ The Irish Government sought Declarations with the EU which were added to the Nice Treaty at an EU Summit in Seville in June 2002 which provided protection for the continuation of Irish neutrality

${ }^{3}$ Guarantees on these issues were added as Protocols in the second referendum on the Lisbon Treaty
} 
referendum on the Lisbon Treaty. It was frequently expressed that as a result of the onset of the economic and financial crisis Ireland was safer as part of a larger economic community that could potentially offer Ireland protection, which Ireland did receive through a three-year Economic Adjustment Programme or Bailout in December 2010 from the Troika (which it exited in December 2013).

Yet, perhaps the economic context was much more marked for the Fiscal Stability Treaty referendum in 2012 than for any other EU-related referendum as a result of the ailing Irish economy and the Irish governments' reliance on a multi-billion Euro loan administered by the EU and the IMF. One of the advantages of the Fiscal Stability Treaty is it addressed only one area: economic policy. This made it much less likely for debate over ratification by social and cultural issues that had become prominent in Nice 1 and Lisbon 1. Ireland was supportive of the Fiscal Stability Treaty - as a small EU member state suffering the effects of the Eurozone crisis and domestic banking failures, Ireland regarded the Fiscal Stability Treaty as a means to regain stability, growth and market confidence (Costello, 2012). And the Irish electorate recognised this and voted to ratify the Fiscal Stability Treaty in May 2012 by $60 \%$ (see Table 1).

Despite the emergence of a potential popular scepticism from 2001-2008 and the financial bailout received in 2010, Irish attitudes towards the EU continued to remain consistently positive. Analysis of large-N survey data; most notably Standard Eurobarometer data from 1972 - 2017 shows that support for the EU in Ireland since 1987 in particular has been above the EU average and reached a record high of $83 \%$ in 2017 (see Figure 1) - with individuals in Ireland believing that membership of the EU is a 'good thing' for Ireland.

\footnotetext{
$<<$ Figure 1 about here $>>$
} 
The robustness of Ireland's support for the EU is reiterated further by Standard Eurobarometer data from 2009 - 2014 at the peak of the economic and financial crisis which demonstrates that the Irish electorate maintained that the EU was the best placed institution to take effective action against the economic and financial crisis (See Figure 2).

$<<$ Figure 2 about here $>>$

This vigour of support by individuals in Ireland for the EU is echoed when examining how individuals in Ireland perceive they have benefited from EU membership. Support for the EU is once again above the EU average since 1984 in particular reaching an all-time high in 2018 of $91 \%$ - the highest across all 28 EU member states.

$<<$ Figure 3 about here $>>$

The individual-level responses in Figure 2 are notable as they highlight that individuals in Ireland regard the Irish state as much less effective in its action to manage the effects of the economic crisis since Spring 2010. Additionally, what is robustly evident from all three analyses here is that despite the financial Bailout from the Troika in 2010 individuals in Ireland want more, not less, EU integration - individuals in Ireland continue to remain enthusiastic supporters of the EU (see Figure 1 and 2) - they believe that membership of the EU is a good thing and that overall Ireland has benefited from membership of the EU.

\section{The Brexit Crisis - Turning Point 2.0}

The vote by the UK to leave the EU on $23^{\text {rd }}$ June 2016 constituted a remarkable shock to both British and UK politics. And this shock resonated just as much in Dublin. While the 
Irish government had put contingency plans in place, the 2016 EU referendum result in the UK placed Ireland in an unenviable and difficult position. The UK is not just Ireland's nearest neighbour. It is one of Ireland's "largest trading partners, the main market for Irish agri-food produce, the geographic link to the continent (Ireland's land bridge) in getting goods to market and its most important ally within the European Council and the Council of Ministers" (O’Brennan, 2019 pp. 2; see Murphy this issue). Brexit therefore represents the single greatest political and economic challenge to Ireland since World War Two.

Ireland's unique circumstances, including the issue of peace in Northern Ireland and the preservation of the Good Friday Agreement (GFA), must be addressed in Brexit negotiations. Firstly, the future trade relationship between the EU and the UK will be crucial to both constituent parts of the island of Ireland. Secondly, the relationship, whether it is the result of EU-UK relations, or a relationship specifically designed to address Ireland's circumstances, does not solely depend on the nature of the border between Northern Ireland and the Republic of Ireland, and no border, whether it is visible or invisible, can create a satisfactory result if the economic arrangements are unsound. Hence, why the Irish government has advocated for the UK, or at a minimum Northern Ireland, to remain in the European Single Market and the Customs Union (Murphy, 2018; see Murphy this issue).

There is undoubtedly an awareness that Ireland has a special case in relation to Brexit. As a senior EU Commission official states "Ireland is a good EU citizen... [... ... they went through the crisis and agony of the [bailout] programme and came out as a poster boy for resilience and toughing it out. So, what is at stake is absolutely enormous" (EU Commission cited in Connelly, 2017 pp. 342). The weight of Ireland's concerns - trade and Northern Ireland - has allowed the Irish government to fuse the two issues in its negotiating strategy. As a Senior Irish diplomat affirms; "the logic of the peace process is based on a method to depoliticize the underlying constitutional problems, and to create a zone of peace and prosperity. That peace 
and prosperity is underlined by the free movement of goods and services" (Irish Diplomat cited in Connelly, 2017 pp. 342). Therefore, Brexit negotiations have demonstrated a remarkable 'reverse asymmetry' (O’Brennan, 2019 pp. 2) in UK-Irish relations as the historical dynamic of British power over Ireland has yielded itself to the inside-outside asymmetrical logic of the Article 50 negotiations. Ireland's status as a privileged EU insider has created a position whereby it can veto any Withdrawal Agreement/Treaty that did not include a Backstop ${ }^{4}$ clause on the Irish border.

Public Opinion support for the Irish governments' negotiating strategy and management thus far of Brexit has been overwhelmingly positive. This is reflected in two opinion polls - The Sunday Business Post/RED C Poll ${ }^{5}$ in January 2019 and the Sky Data Poll ${ }^{6}$ in February 2019 which ask a nationally representative sample of respondents' questions which pertain specifically to individual attitudes towards Brexit in Ireland. The Sunday Business Post/Red C poll asks two specific questions relating to the Backstop in particular. And the findings are thought-provoking $-70 \%$ of respondents agreed that the Irish government should refuse to put up border infrastructure if there is a hard Brexit (24\% disagree and $6 \%$ were unsure) and 64\% disagreed that the Irish government should drop the Backstop from the Brexit Withdrawal Agreement in order to help former Prime Minister Theresa May ${ }^{7}$ get the deal through the House of Commons ahead of the UK's departure from the EU on $29^{\text {th }}$ March $2019^{8}$.

\footnotetext{
${ }^{4}$ The Backstop is an insurance policy to avoid a hard border between Northern Ireland and the Republic of Ireland if a free trade deal between the UK and the EU is not reached by the end of the Transition period of 2020. For a full and comprehensive analysis of the Irish Backstop please see Brexit and the Backstop" Everything You Need to Know, The UK In Changing Europe, $11^{\text {th }}$ February 2019, available at: https://ukandeu.ac.uk/brexit-and-thebackstop-everything-you-need-to-know/ Accessed: 17/04/19

5 The Sunday Business Post/Red C Poll interviewed a random sample of 1,000 adults $(\mathrm{N}=1,000)$ aged $18+$ by telephone between $17^{\text {th }}-24^{\text {th }}$ January 2019. Respondents were asked four questions and asked to respond either Agree, Disagree or Unsure.

${ }^{6}$ The Sky Data Poll interviewed a nationally representative sample of 1,611 Sky Customers in the Republic of Ireland $(\mathrm{N}=1,611)$ online from $1-4^{\text {th }}$ February 2019. Data are weighted to the profile of the population.

${ }^{7}$ Prime Minister Theresa May stepped down as Leader of the Conservative Party on $7^{\text {th }}$ June 2019 triggering a leadership contest within the Conservative Party and thus a new UK Prime Minister

${ }^{8}$ At the time of writing an extension to Article 50 until $31^{\text {st }}$ October 2019 had been granted by the EU. Therefore, the UK did not leave the EU as scheduled on $29^{\text {th }}$ March 2019.
} 
This is reiterated further in the Sky Data Poll where 79\% of individuals in Ireland think that the Irish government should persist for a legal guarantee that there will be no hard border on the island of Ireland with just 7\% of individuals in Ireland believing that the Irish government should prioritize a No Deal Brexit.

Findings from the Sky Data poll are also positive for the Irish government and for the EU $-60 \%$ of respondents believe the Irish government has done a good job in negotiating Brexit (17\% think the Irish government has done a bad job and $23 \%$ unsure). In contrast, a vast majority $-84 \%$ of individuals in Ireland think that the UK government had done a bad job in Brexit negotiations with just $6 \%$ believing it has done a good job. Finally, from an economic perspective, Irish respondents continue to align and display positive support for the EU. When asked to choose who to cut economic ties with $81 \%$ of respondents said the UK, while only $19 \%$ said the EU.

\section{The possibility of an Irexit}

Relative to the rest of the EU, Ireland is especially vulnerable to the fallout from Brexit, both economically and politically. As a result, some argue that an Irish exit, or Irexit, from the EU would benefit the nation. The question of Irexit has developed primarily as an economic argument implying that Ireland will be left marginalised, peripheral and dependent post Brexit. Therefore, Irexit would allow for reintegration with the UK, thus reinstating close ties with one of its largest trading partners. From a political perspective, the formation of the Irexit Freedom Party coined as a "national movement of the Irish people which has as its primary objective the re-establishment of the national independence and sovereignty of Ireland and the restoration of national democracy to be achieved through leaving the European Union" (Irexit Freedom party, 2019) has politicised the Irexit debate. Primarily, the movement draws upon those individuals who feel aggrieved, display anti-establishment sentiments and who prescribe to the 
left-behind thesis (Goodwin \& Heath 2016a). However, there are also disconnects between the disparate elements in those attending events held by the Irexit Freedom Party with many holding divergent views on immigration as well as the lack of leadership and direction of the group.

Overall however, there are four fundamental economic and political problems with the Irexit thesis. Firstly, from an economic perspective, the stance on a possible Irexit omits the question of how Ireland developed economic independence and moved on from political domination by the UK when it joined the EU in 1973. Irish accession to the EU enabled the diversification in trade and investment, including the European Single Market, but also attracting Foreign Direct Investment (FDI) from the USA. Research by Davies \& Francois (2018) also highlights that an economic realignment with the UK, moving away from the European Single Market, would "substantially worsen the impacts of Brexit, with lower-skill and agricultural workers being disproportionately affected" (Davies \& Francois, 2018 p. 455). Emphasizing that while the UK is indeed one of Ireland's most important trading partners, trade with the rest of the EU is much more important. Secondly, from a political perspective, the equal partnership between the UK and Ireland as EU member states facilitated negotiations on the issue of peace in Northern Ireland and in particular the Good Friday Agreement (See Murphy this issue; Murphy, 2018; Brennan, 2019). Thirdly, while populism may have ignited the two biggest political shocks of recent times; Brexit and the election of Trump as President of the USA, in Ireland there has been little proliferation on the Conservative hard right. This dispels, from a political and theoretical perspective, the basis and rationale for the Irexit movement. Fourthly and finally, public opinion support for the EU in Ireland is consistently positive and there is little appetite among individuals in Ireland to leave the EU. This can be seen both longitudinally through large-N survey data and through public opinion polls.

Positive public opinion support for the EU in Ireland is reiterated across several data 
sources. The annual European Movement Ireland/RED C Poll in March $2018^{9}$ found that $92 \%$ of individuals in Ireland believe that Ireland should remain a part of the EU, 87\% of individuals believe that on balance Ireland has benefited from being a member of the EU and that despite the UK leaving the EU (i.e. Brexit) $87 \%$ of individuals in Ireland disagree that Ireland should also leave the EU. These are robust findings for both support for the EU and the Irexit debate. Beginning with support for the EU, overall the findings from the EMI/RED C Poll largely echo the findings from Standard Eurobarometer data. Between 2013 and 2018, when asked the question "Taking everything into consideration, Ireland has on balance benefited from being a member of the EU" the lowest level of support for the EU in Ireland was $80 \%$ (Standard Eurobarometer data 2013) while the highest was 91\% (Standard Eurobarometer data 2018). Overall however, as Figure $4^{10}$ illustrates there is little variation between the two data sources demonstrating the robust public opinion support for the EU in Ireland.

$$
<<\text { Figure } 4 \text { About Here }>>
$$

When considering the case for Irexit it is necessary to examine opinion polling data from 2018 as well as the latest Standard Eurobarometer data findings. In the 2018 European Movement/Red C Poll there are two questions which examine Irexit. While there is understandable uncertainty about what changes and challenges Brexit will herald for Ireland, individuals are clear that leaving the EU is not in Ireland's interests. In the 2018 European Movement Ireland/RED C Poll, when asked 'If the UK were to leave the EU, Ireland should

\footnotetext{
9 The RED C Poll commissioned by the European Movement Ireland has been conducted annually since 2013 (apart from 2014 when no poll was commissioned) in order to ascertain the views of Irish people on a variety of issues related to Ireland - EU relations. The 2018 poll was conducted between $15^{\text {th }}-21^{\text {st }}$ March 2018 among a representative sample of 1,000 individuals in Ireland $(\mathrm{N}=1,000)$ aged $18+$. A series of statements were read out and respondents were asked by Red C to Agree Strongly, Agree Slightly, Disagree Strongly or Disagree Slightly. ${ }^{10}$ The question "Taking everything into consideration, Ireland has on balance benefited from being a member of the EU" was asked in both the European Movement Ireland/Red C Poll and Standard Eurobarometer survey allowing a direct comparison between both polling and survey data. Please note that no European Movement Ireland/RED C Poll was conducted in 2014 thus there is unfortunately a lapse in the time series analysis.
} 
leave too" only $11 \%$ of individuals in Ireland agree that Ireland should in fact leave the EU. This demonstrates a dramatic decline from 2013 when support for Ireland leaving the EU in the event of Brexit was at $29 \%{ }^{11}$.

$$
<<\text { Figure } 5 \text { About Here }>>
$$

In the same poll, individuals were asked whether Ireland should remain a part of the $E U$ with $92 \%$ of respondents agreeing with the statement. Again, this finding demonstrates consistent and positive support for the EU since 2013 with support for membership of the EU increasing since year on year since 2013 (See Figure 6).

\section{$<<$ Figure 6 About Here $>>$}

In addition, one of the most comprehensive opinion polls conducted on EU membership in Ireland since the 2016 Brexit vote in the UK compliments the findings of the 2018 European Movement/Red C Poll findings. When asked whether Ireland should remain a member of the EU, $94 \%$ of respondents in the Ireland Thinks ${ }^{12}$ poll agreed with this statement. Moreover, in the latest 2018 Standard Eurobarometer ${ }^{13}$ individuals were asked "If a referendum was held tomorrow regarding Ireland's membership of the EU, how would you vote?" with $85 \%$ of individuals stating they would vote to remain in the EU - the highest of all twenty-seven EU member states and 19\% above the EU average.

\footnotetext{
${ }^{11}$ Please note that no European Movement Ireland/RED C Poll was conducted in 2014.

12 The Ireland Thinks poll was conducted between $15^{\text {th }}-24^{\text {th }}$ August 2018 among a random sample of 942 individuals in Ireland aged $18+$.

${ }^{13}$ Standard Eurobarometer 90.1 was conducted between $8^{\text {th }}-26^{\text {th }}$ September 2018 among all EU27 $(N=27,601)$ aged $16+$. For Ireland, $\mathrm{N}=1,001$
} 
Overall, the Irexit debate is a crude caricature of Ireland's political and economic situation which falls back on inherent clichés (i.e. Ireland is a small, peripheral member state, reliance on the UK etc.), disregarding Ireland's success in Brexit negotiations (i.e. ensuring the UK cannot move forward to trade negotiations until the unique Irish issues have been full addressed) and provides no indication of what Irexit and the future relationship with the EU would look like. But perhaps more importantly, it demonstrates a rudimentary understanding of Irish attitudes towards the EU. An Irexit is highly questionable.

\section{IRELAND'S FUTURE RELATIONSHIP WITH THE EU: MOVING ON FROM THE ECONOMIC CRISIS AND EMBRACING BREXIT}

The economic crisis and the Irish context highlights the heightened risk of economic adversity for individuals as a result of rising economic problems in both Ireland and the EU. These individuals are more supportive of income distribution as a means to minimize their own economic insecurity (Simpson \& Loveless 2017, Simpson 2018) with the focus on European integration now moving towards a more individualist egocentric perspective. European integration and governance have been centrally important in the economic transformation of Ireland, particularly through the alignment of state strategy with the action of economic and social interests. Given the economic and financial crisis, inequality not only heightened individual level concerns about economic stability, but it has also demonstrated that context, especially in the case of Ireland, is important and has directly influenced politics (Simpson, 2018).

In many ways, the outcome of the UK's referendum on EU membership was not surprising. Firstly, public opinion in the UK has consistently been the most Eurosceptic electorate in the EU since it joined the EU in 1973. Secondly, it is well-established that referendums on European integration are highly unpredictable and that voters often reject 
proposals put to them by the government even when supported by a consensus among mainstream political parties and experts (Franklin et al 1994, 1995; Hobolt, 2009). One the one hand, the outcome of the EU referendum is a unique event since no other member state has decided to exit the EU. One the other hand, the sentiments that led to the outcome of Brexit are by no means a British phenomenon with anti-immigration, anti-establishment and stark demographic divides between the winners and losers of the European integration process. Typically Remain voters were likely to be younger, a graduate of a university and receiving a higher income while Leave voters were likely to be older, with a lower level of educational attainment and earning a low income (Goodwin \& Health, 2016a \& 2016b). The challenge of Brexit for the EU, and for the member states, is that many voters across Europe see the EU as part of the problem rather than the solution when it comes to protecting ordinary citizens from the challenges of an ever more integrated world.

However, Ireland again somewhat bucks this trend as research shows that even during the economic and financial crisis and financial bailouts received from the Troika/International Monetary Fund (IMF) Ireland remained avid supporters of European integration (Simpson 2018). Yet, in the context of Brexit, since Ireland is the member state which is most exposed to the economic effects of Brexit as a result of all trade between the UK and Ireland being governed under the EU framework of the Customs Union and the European Single Market could Brexit determine a potential transformation in Irish public opinion towards the EU which wasn't experienced during the economic and financial crisis and goes beyond the feeble Irexit debate? One which focuses on European integration in a more policy orientated perspective?

Overall, Standard Eurobarometer data does not contain specific questions about Brexit. However, if the issue of Brexit permeates mass public opinion in Ireland we would expect it to influence individual level attitudes on the current economic situation in Ireland and in particular Ireland's future economic prospects. Figure 7 asks respondents "What do you think 
are the two most important issues facing [Ireland]?" from 2007 - 2018 assessing issues such as crime, the economic situation (of Ireland), the cost of living, unemployment, housing, immigration and health and social security. This Eurobarometer data allows an examination of key issues facing Ireland during the economic and financial crisis and following the Brexit vote.

Firstly, focusing on the economic and financial crisis, between 2008 and 2015 the two most important issues individuals believed Ireland was facing were the economic situation and unemployment. The economic situation was regarded as the most important issue for Ireland in 2008 and the second most important issue in the period $2009-2014^{14}$. While the issue of unemployment was considered to be the most important issue facing Ireland between 2009 2014. These findings are consistent with previous research that identifies individuals experiencing economic adversity during the economic and financial crisis as a result of rising economic problems in both Ireland and the EU. Secondly, from 2015 - 2018, a period which captures the context of pre, and (immediate) post, Brexit individuals report more policy orientated issues as the most important issues facing Ireland, most notably housing and health and social security. From 2015 - 2018, housing was regarded as the most important issue for Ireland while health and social security was viewed as the second most important issue.

However, perhaps the most notable shift in key issues since 2015 is the fact that individuals' economic perceptions and expectations are overwhelmingly positive In Ireland. Since 2015 , there has been a steady decline in individuals reporting that the economic situation is one of the most important issues in Ireland - from 13\% in 2015 to just $8 \%$ in 2018 - which is between six to seven percentage points lower than the EU average for the same period. The same pattern can be reported for the issue of unemployment. Since 2016, individuals have

\footnotetext{
${ }^{14}$ Please note that the data is unavailable for the question What do you think are the two most important issues facing [Ireland]? as this question was not asked in any Standard Eurobarometer in 2011 therefore there is a break in the time series.
} 
reported a decline in unemployment as the most important issue for Ireland - from $24 \%$ in 2016 to $14 \%$ in 2018 - and between four and nine percentage points lower than the EU average for the same period. The positive shift in public opinion towards the economy during a period of political and potential economic instability in light of Brexit highlights there are limited concerns for economic pessimism in Ireland.

$<<$ Figure 7 About Here $>>$

Standard Eurobarometer data can also examine what individuals believe to be the most important issues they are facing at the moment allowing an analysis at the individual-level as well as the macro-level. Figure 8 asks respondents "And personally, what are the two most important issues you are facing at the moment? " from $2009-2018^{15}$ assessing the same issues such as crime, (personal) economic situation, the cost of living, unemployment, housing, immigration and health and social security. This Eurobarometer data allows an examination of key issues facing individuals in Ireland during the economic and financial crisis and following the Brexit vote. Between 2009 - 2014, the two most important issues facing individuals in Ireland are the economic situation (the most important issue in 2009 and 2010, second most important issue in 2012), unemployment (the second most important issue in 2009 and 2010) and the cost of living (most important issue in 2012, 2013 and 2014). Again, these findings are consistent with the Eurobarometer data outlined in Figure 7 as well as previous research that identifies individuals experiencing economic adversity during the economic and financial crisis

\footnotetext{
15 Please note that the data is unavailable for the question And personally, what are the two most important issues you are facing at the moment]? as this question was not asked in any Standard Eurobarometer in 2011 therefore there is a break in the time series.
} 
as a result of rising economic problems in both Ireland and the EU. Put simply, during the economic and financial crisis economic pessimism at the individual-level was widespread.

From 2015 - 2018 however, the two most important issues facing individuals are both economic and policy orientated. From 2015, the cost of living is reported as the most important issue individuals are facing in Ireland with health and social care reported as the second most important issue for individuals. What is noteworthy here is that both of these issues are far higher in Ireland than the EU average. This demonstrates that there is the possibility of a potential Brexit effect and sense of economic pessimism at the individual-level not experienced at the macro-level. However, it may be argued that for individuals in Ireland the question of whether and perhaps how Brexit will have an impact on Ireland at the macro-level and individual-level may not have a clear answer. There are indeed no specific Brexit questions from which to draw upon in Standard Eurobarometer data and Brexit is being contextualized in economic terms. Yet, what is clear is policy-orientated issues concerning health care, social care and principles of the welfare state are of great concern for individuals in Ireland.

$$
<<\text { Figure } 8 \text { About Here }>>
$$

\section{DISCUSSION}

The Irish government's concerns about Brexit were first outlined in the 2014 National Risk Assessment and outlined that a period of uncertainty regarding the UK's relationship with the EU would have an impact on Ireland in three areas. Firstly, in the pursuit of Ireland's objectives as an EU member state, secondly regarding bilateral relations with the UK including the economic and trading relationship and thirdly issues in relation to Northern Ireland. The UK decision to leave the EU apportioned a considerable shock to Irish national interests. There are serious economic concerns about the potential detrimental effect of the UK being outside 
the European Single Market and Customs Union. The erection of barriers to trade between the UK and Ireland poses fundamental risks to the Irish economy while the effects of Brexit on the Common Travel Area (CTA) are also problematic (See Murphy, this issue; Murphy, 2018). However, when examining public opinion and the effect that Brexit will have on the macrolevel and individual-level there does not appear to be a Brexit effect regarding the Irish economy - overall, attitudes towards the economy and individuals' personal economic situation are overwhelmingly positive. Perhaps a potential Brexit effect is still too early to determine for mass public opinion for two reasons. Firstly, there are no questions relating to Brexit specifically in the Standard Eurobarometer data over this time period and secondly the potential effects of Brexit are still in fact not known. This makes examining mass public opinion in relation to attitudes towards Brexit cumbersome.

However, it can be posited from both sets of opinion polling data that an Irexit is unlikely and that individuals in Ireland believe that EU membership is a good thing - this is a robust finding as it is also reflected in the analyses of Standard Eurobaromter also. One of the central components of the Irish government's approach to Brexit has been to engage with civil society and stakeholders in particular creating an All-Island Civic Dialogue on Brexit a participative and consultative exercise that aimed to hear directly about the all-island implications of Brexit from a variety of stakeholders and across a wide range of sectors. The All-Island Civic Dialogue provided new opportunities for methods of public discussion among civil society actors which had not existed previously. Over time, these forums may conceivably elevate public knowledge of the EU and therefore impact on attitudes towards the EU.

\section{CONCLUSION}

Ireland, and perhaps more specifically Irish public opinion, has weathered the storm of the economic and financial crisis and (so far) the Brexit crisis and the debate around a potential 
Irexit. While an Irexit is unlikely, Ireland's relationship with the EU will not be without its challenges. Firstly, in the context of Brexit on issues such as the economic impact Ireland will experience as a consequence of the UK leaving the EU as well as questions pertaining to the border between Northern Ireland and the Republic of Ireland. Secondly, in the context of the future relationship with the EU most notably the Apple tax ruling. While a knowledge deficit continues to exist among the mass public in Ireland with regards to the EU the salience of EU membership and therefore support for the EU is consistently strong, robust and shows little sign of abating. Brexit has forced Ireland to think anew about its relationship with the UK and the EU and instead of turning towards an historical periphery Ireland recognizes that current challenges are global and do not respect borders. As a consequence, Ireland is best placed to meet these changes through continued cooperation and engagement subsequently influencing solutions as part of the EU. Brexit may indeed mean Brexit but for Ireland remaining a member state of the EU is in its national interest - and public opinion recognises this. 
TABLES \& FIGURES

TABLES

Table 1: EU-Related Referendums in Ireland 1973 - 2012

\begin{tabular}{|c|c|c|}
\hline EU-Related Treaty & Date, Month, Year & Result (incl. turnout) \\
\hline $\begin{array}{l}\text { Accession to the European } \\
\text { Community }\end{array}$ & $10^{\text {th }}$ May 1973 & $\begin{array}{l}\text { Yes } 83.09 \% \\
\text { No } 16.91 \% \\
\text { Turnout } 70.88 \%\end{array}$ \\
\hline $\begin{array}{l}\text { Treaty on Single European } \\
\text { Act }\end{array}$ & $26^{\text {th }}$ May 1987 & $\begin{array}{l}\text { Yes } 69.92 \% \\
\text { No } 30.08 \% \\
\text { Turnout } 44.09 \%\end{array}$ \\
\hline $\begin{array}{l}\text { Treaty of European Union } \\
\text { (Maastricht) }\end{array}$ & $11^{\text {th }}$ June 1992 & $\begin{array}{l}\text { Yes } 69.05 \% \\
\text { No } 30.95 \% \\
\text { Turnout } 57.31 \%\end{array}$ \\
\hline Treaty of Amsterdam & $22^{\text {nd }}$ May 1998 & $\begin{array}{l}\text { Yes } 61.74 \% \\
\text { No } 38.26 \% \\
\text { Turnout } 56.20 \%\end{array}$ \\
\hline Nice Treaty 1 & $7^{\text {th }}$ June 2001 & $\begin{array}{l}\text { Yes } 46.13 \% \\
\text { No } 53.87 \% \\
\text { Turnout } 34.79 \%\end{array}$ \\
\hline Nice Treaty 2 & $19^{\text {th }}$ October 2002 & $\begin{array}{l}\text { Yes } 62.89 \% \\
\text { No } 37.11 \% \\
\text { Turnout } 49.47 \%\end{array}$ \\
\hline Lisbon Treaty 1 & $12^{\text {th }}$ June 2008 & $\begin{array}{l}\text { Yes } 46.60 \% \\
\text { No } 53.40 \% \\
\text { Turnout } 53.13 \%\end{array}$ \\
\hline Lisbon Treaty 2 & $2^{\text {nd }}$ October 2009 & $\begin{array}{l}\text { Yes } 67.13 \% \\
\text { No } 32.87 \% \\
\text { Turnout } 59 \%\end{array}$ \\
\hline Fiscal Treaty & $31^{\text {st }}$ May 2012 & $\begin{array}{l}\text { Yes } 60.29 \% \\
\text { No } 39.71 \% \\
\text { Turnout } 50.60 \%\end{array}$ \\
\hline
\end{tabular}

Source: Central Statistics Office (CSO) Ireland 


\section{FIGURES}

Figure 1: Support for the EU in Ireland 1973-2017

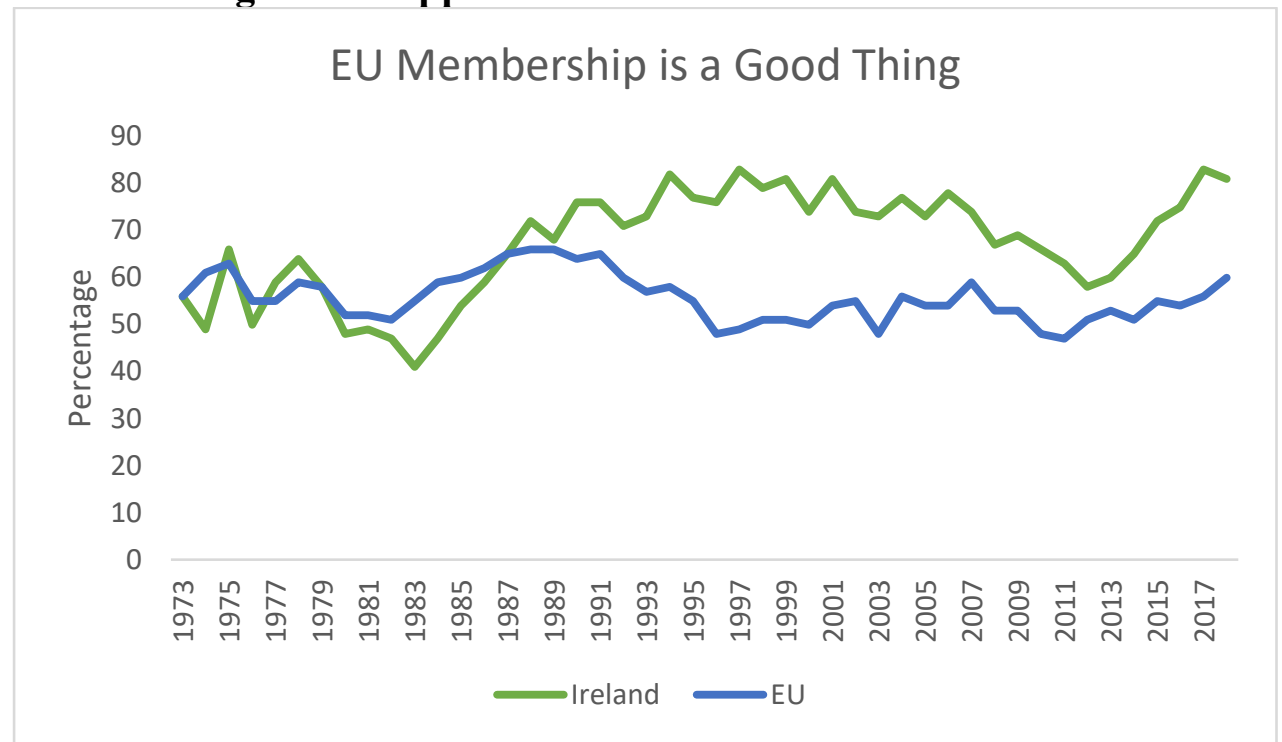

Source: Standard Eurobarometer Data 1973-2018, N=1,009

Figure 2: Effective action against the economic \& financial crisis 2009-2014

Effective Action Against Effects of Economic \& Financial Crisis 20092014

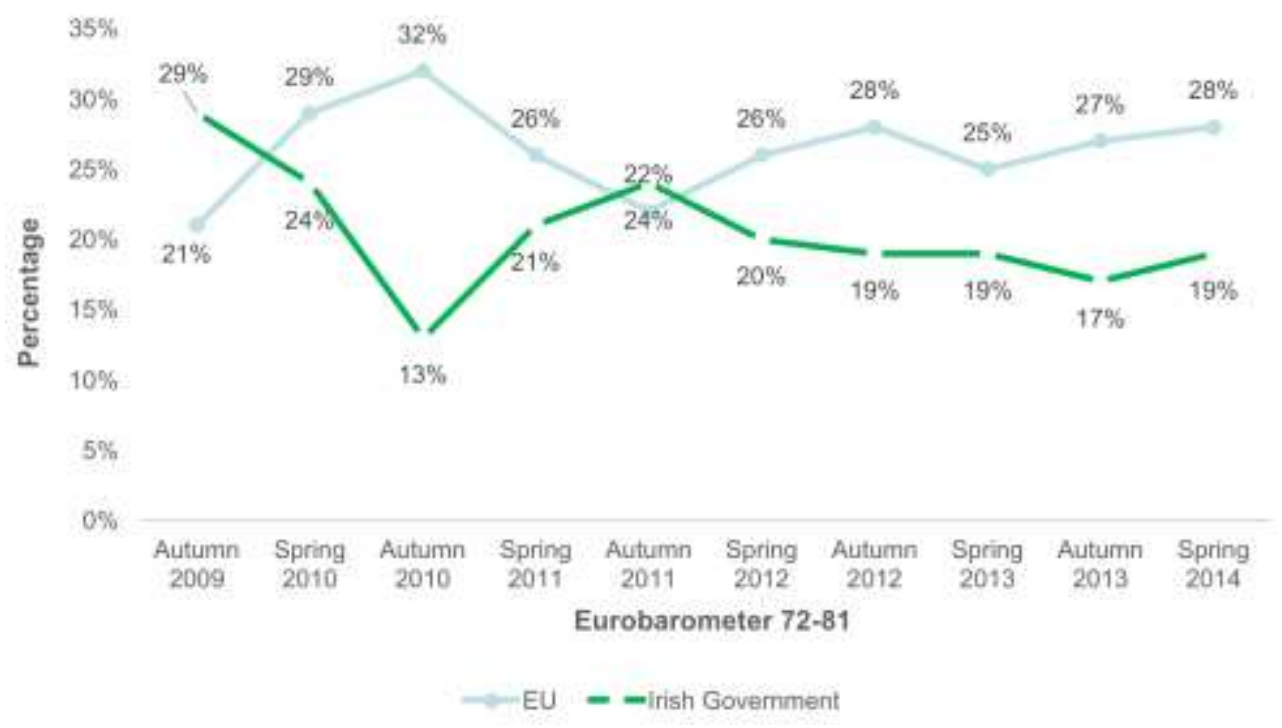


Figure 3: Benefited from EU Membership 1984-2018

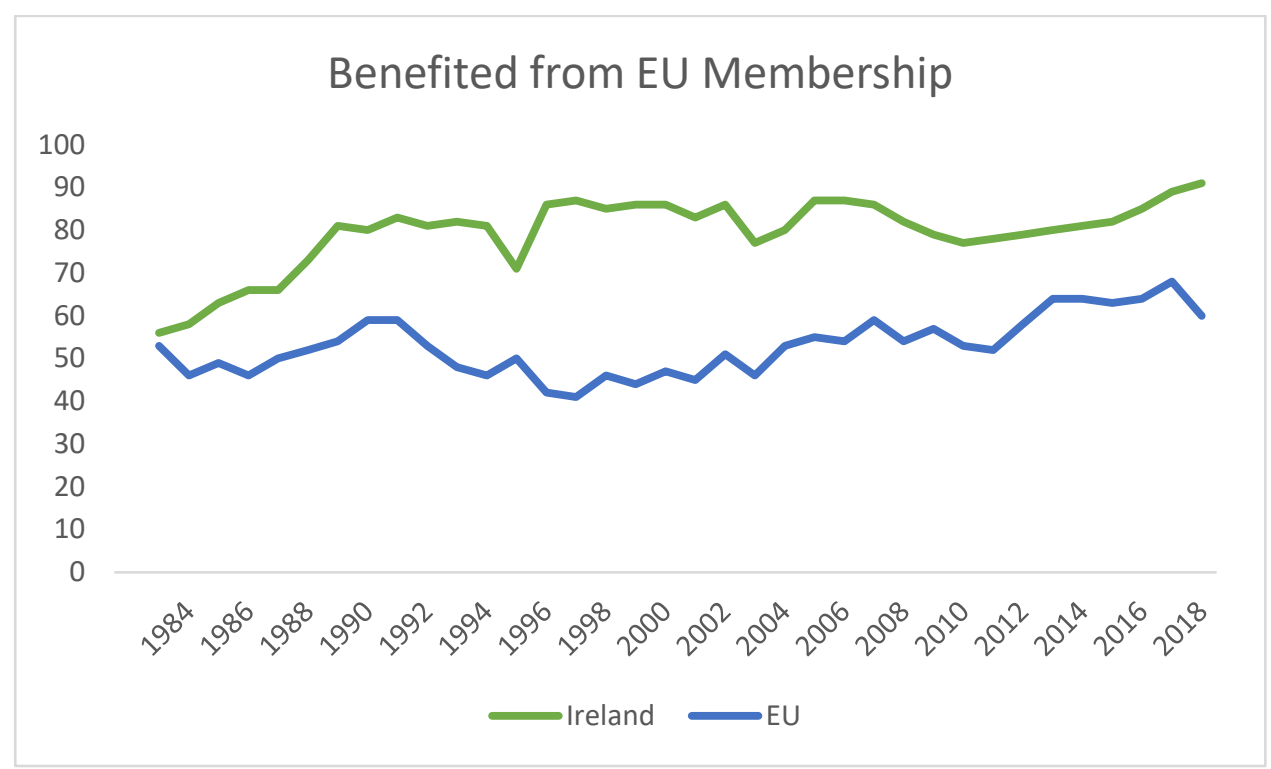

Source: Standard Eurobarometer Data 1984 - 2018, N=1,016

Figure 4: Benefited from EU Membership 2013 - 2018 Survey \& Polling Data

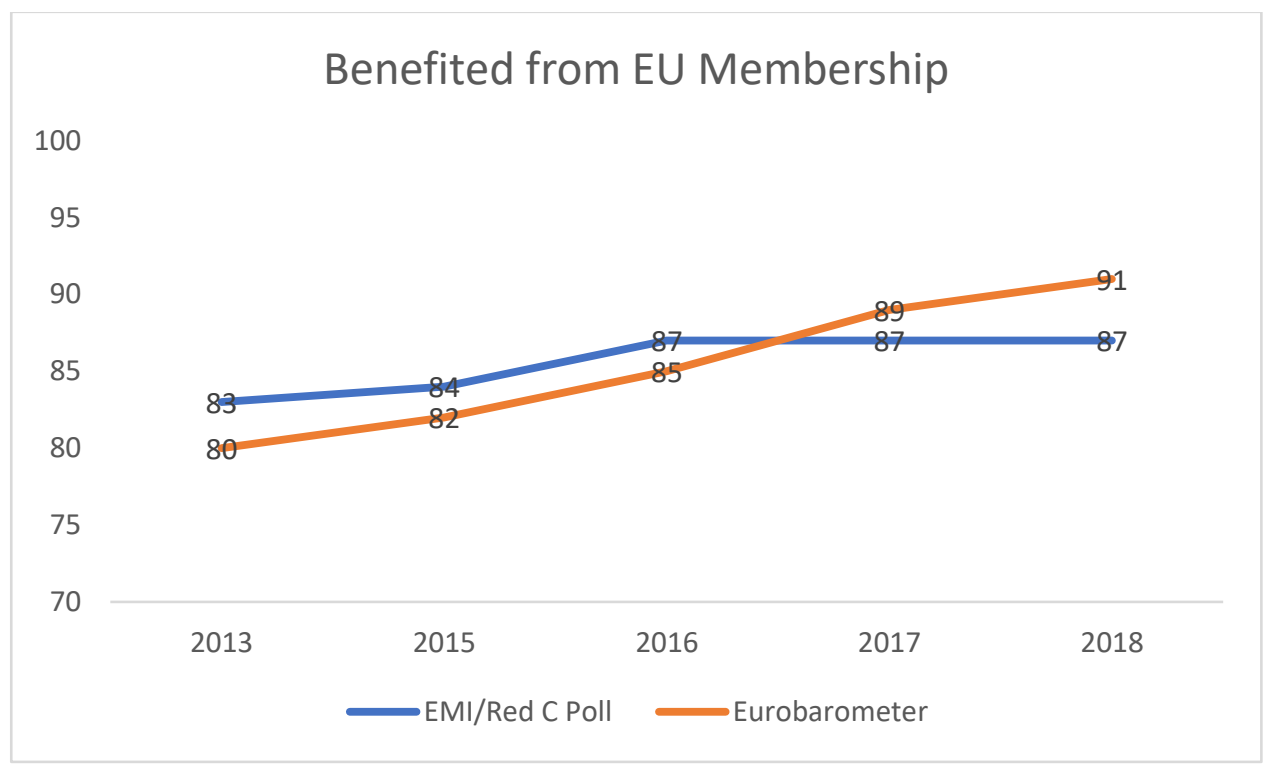

Source: EMI/RED C Poll $2013-2018, \mathrm{~N}=1,000$ \& Standard Eurobarometer Data $2013-2018, \mathrm{~N}=$ 1,016 
Figure 5: Brexit should lead to Irexit

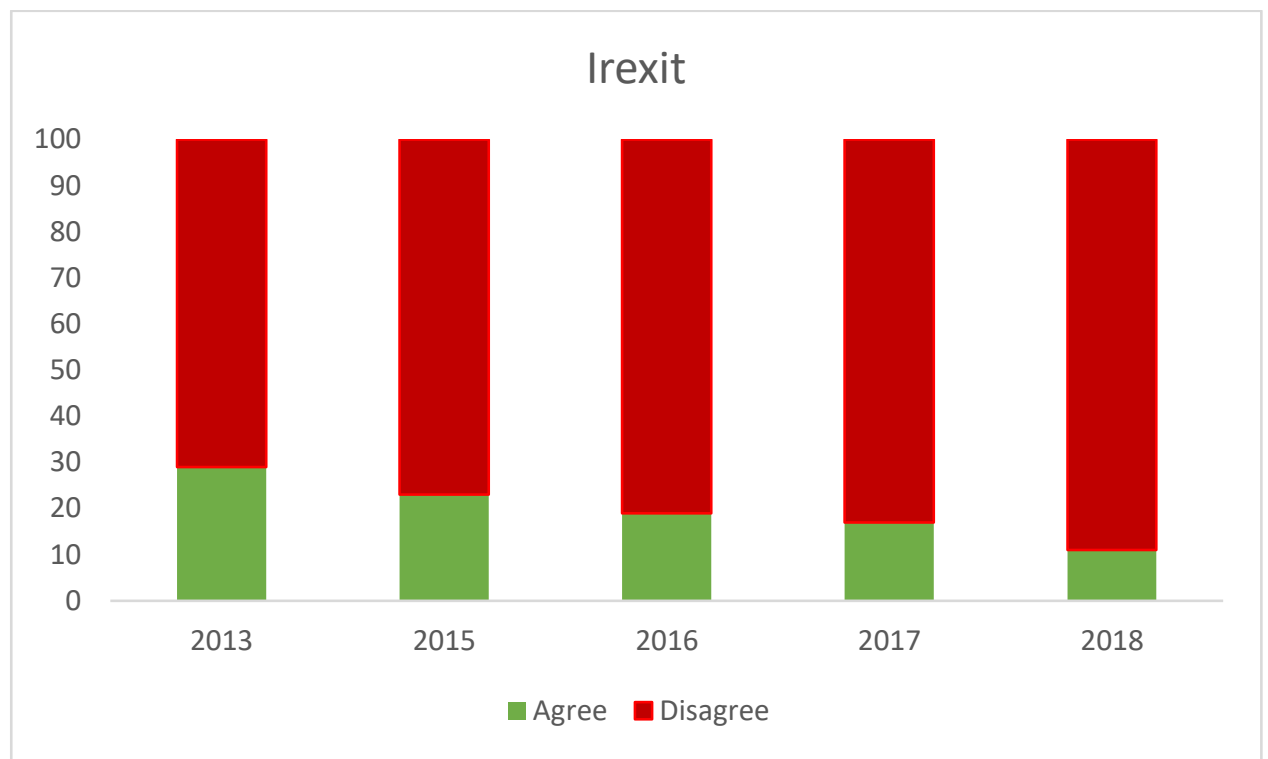

Source: EMI/RED C Poll $2013-2018, \mathrm{~N}=1,000$

Figure 6: Ireland should Remain Part of EU

Ireland Should Remain Part of EU

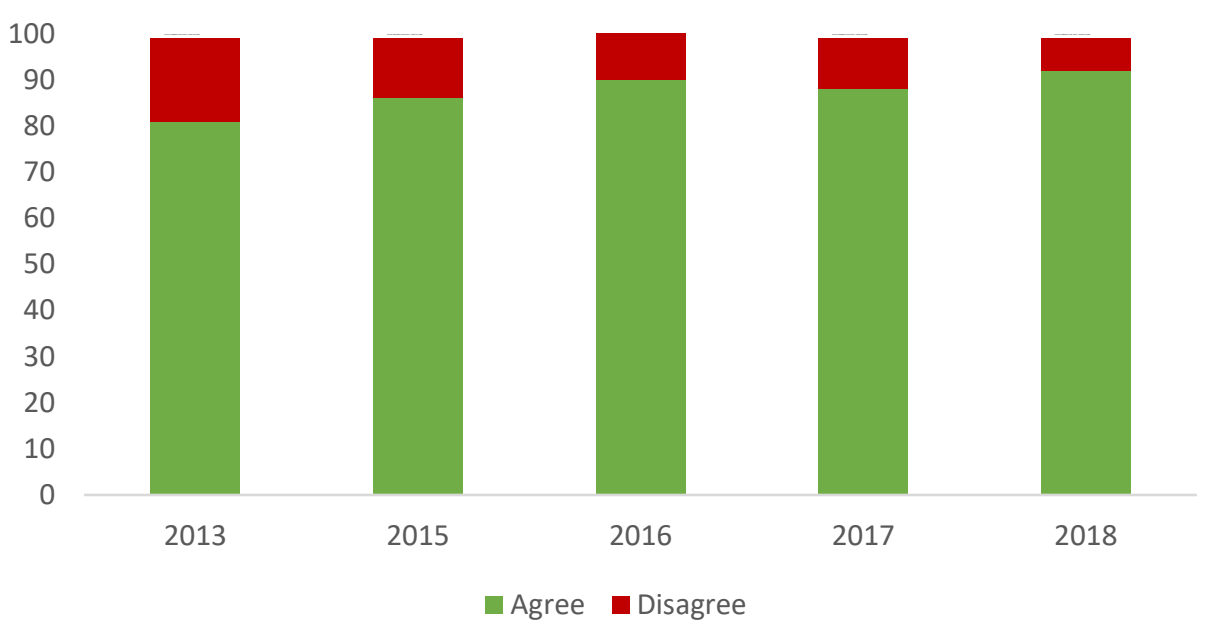

Source: EMI/RED C Poll $2013-2018, \mathrm{~N}=1,000$ 
Figure 7: Most Important Issue for Ireland 2007 - 2018

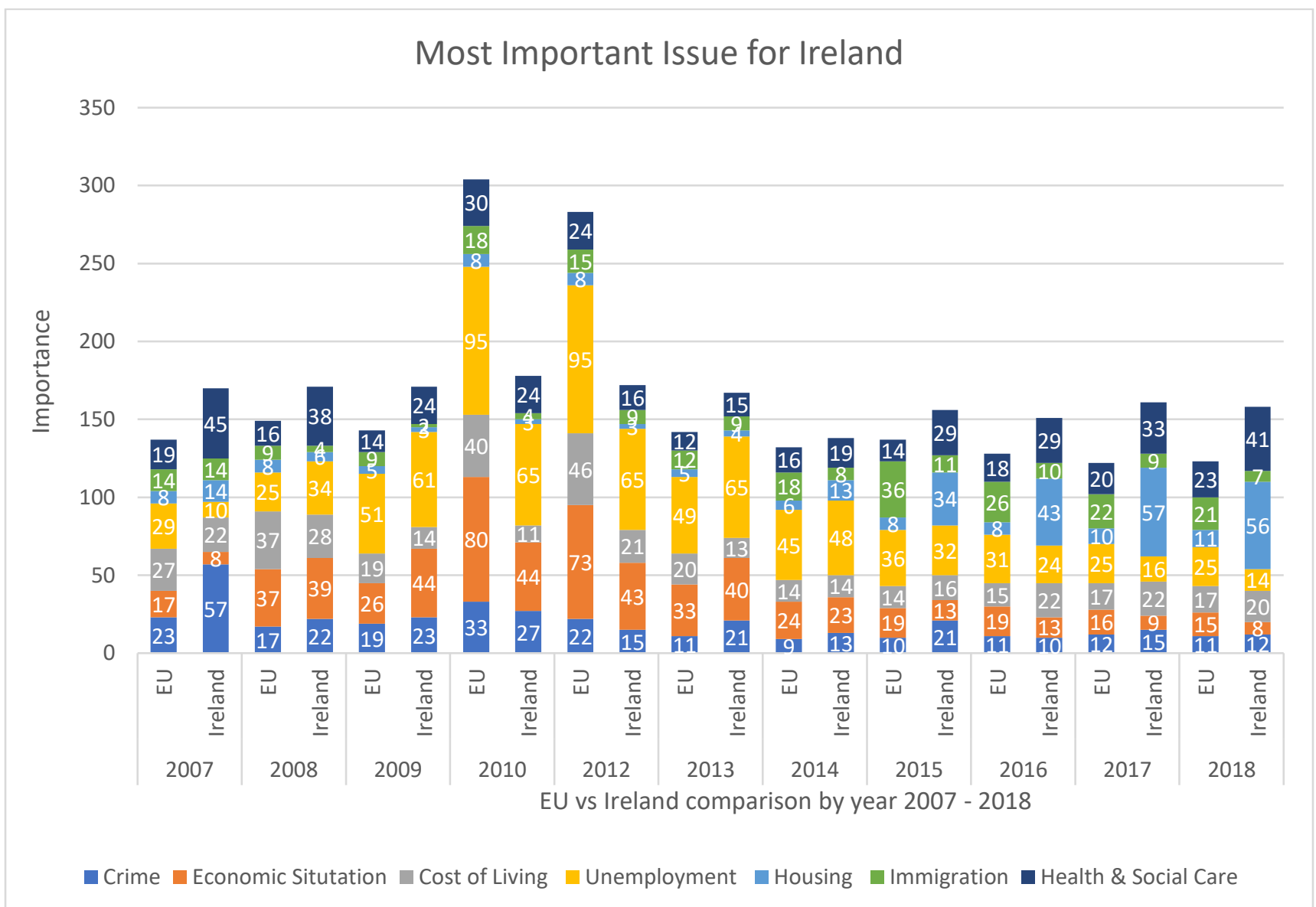

Standard Eurobarometer data $2007-2018 . \mathrm{N}=1,000$ 
Figure 8: Most Important Issue for you Personally 2009 - 2018

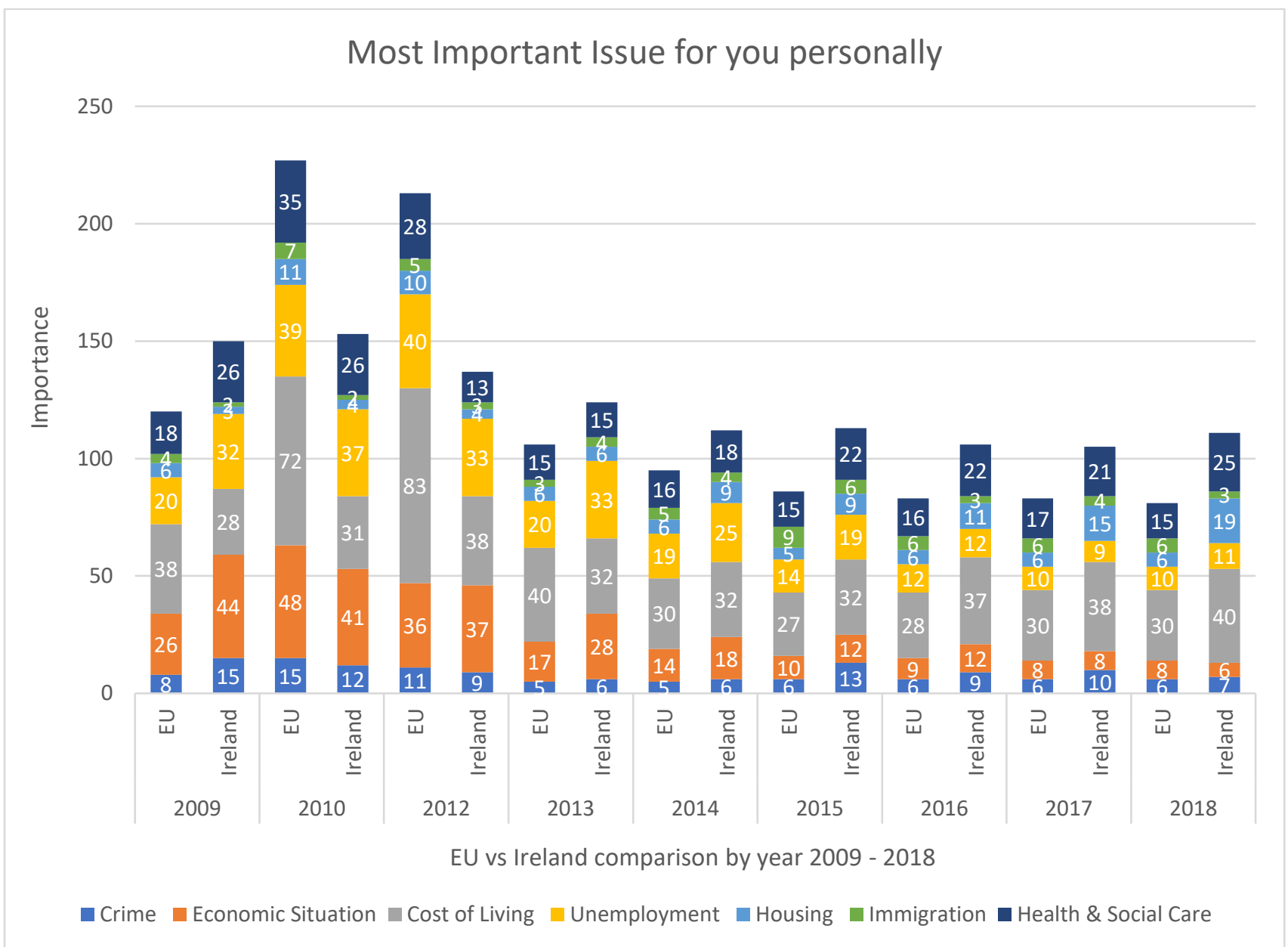

Standard Eurobarometer data $2009-2018$ N=1,000 


\section{BIBLIOGRAPHY}

Adshead, M. \& Tonge, J. (2009) Politics in Ireland: convergence and divergence in a twopolity island, Palgrave and Macmillan

Coakley, J. (2005) 'Irish Public Opinion and the New Europe" in in Holmes, M. (ed.) Ireland and the European Union, pp. 94-114

Connelly, T. (2017) Brexit and Ireland: The Dangers, The Opportunities and the Inside Story of the Irish Response, Penguin: Ireland

Costello, T. (2012) “The Fiscal Stability Treaty Referendum 2012”, Irish Political Studies, Vol. 29, No. 3, pp. 457-470.

Davies, R. B. \& Francois, J. (2018) "Making the Worst of a bad Situation: A Note on Irexit", The Economic and Social Review, Vol. 49, No. 4, pp. $455-462$

European Movement/Red C Poll "Ireland and the EU" 2013-2018, available at: https://www.europeanmovement.ie/programmes/ireland-and-the-eu-poll/ Accessed: $17 / 06 / 19$

Fitzgibbon, J. (2013) "Citizens Against Europe? Civil Society and Eurosceptic Protest in Ireland, the United Kingdom and Denmark", Journal of Common Market Studies, Vol. 51, No. 1, pp. $105-121$

Franklin, M. Van der Eijk, C., \& Marsh, M. (1995) "Referendum outcomes and trust in government: public support for the EU in the wake of Maastricht, West European Politics, Vol. 18, No. 3. pp. 101-117

Garry, J., Marsh, M., \& Sinnott, R., (2005) 'Second-Order versus Issue-voting effects in EU Referendums Evidence from the Nice Treaty Referendums", European Union Politics, Vol. 6, No. 2, pp. 201-221

Garry, J. (2013) "Direct Democracy and regional integration: Citizens' perceptions of treaty implications and the Irish reversal on Lisbon", European Journal of Political Research, Vol. 52, pp. 94-118.

Gilland, K. (2002), "Ireland and European Integration", in Goldmann, K. \& Gilland, K. (eds.) Nationality versus Europeanisation: the view of the nation in four countries, Stockholm: Dept. of Political Sciences, Stockholm University, pp. 166-84

Glencross, A. \& Trechsel, A. (2011) "First or Second order referendums? Understanding the votes on the EU Constitutional Treaty in Four EU Member States", West European Politics, Vol. 34, No. 4, pp. 755-722

Goodwin, M. J. \& Heath, O. (2016a) "The 2016 referendum, Brexit and the left-behind: an aggregate-level analysis of the result”, Political Quarterly, Vol. 87, Issue 3, pp. 323 332

Goodwin, M. J. \& Heath, O. (2016b) "Brexit vote explained: poverty, low skills and lack of opportunities, Joseph Rowntree Foundation

Hobolt, S. (2016) "The Brexit Vote: a divided nation, a divided continent", Journal of European Public Policy, Vol. 23, Issue 9, pp. 1259 - 1277

Holmes, M. (2005) "Irish Approaches to European Integration", in Holmes, M. (ed.) Ireland and the European Union, pp. 1-14

Holmes, M. (ed.) (2005) Ireland and the European Union, Manchester University Press

Ireland Thinks "Brexit Poll", Available at: https://www.irelandthinks.ie/blog Accessed: 17/06/19

Irexit Freedom Party (2019) 'Our Manifesto" available at: https://www.irexitfreedom.ie Accessed: 17/04/19

Kennedy, R. \& Sinnott, R. (2006), "Irish Social and Political Cleavages" in Garry, J. \& Payne, D. (eds.) Irish Social and Political Attitudes, pp. 78-94 
Kennedy, R. \& Sinnott, R. (2007), “Irish Public Opinion towards European Integration”, Irish Political Studies, Vol. 22, No. 1, pp. 61-81

Kenworthy, L. \& McCall, L. (2008) "Inequality, public opinion and redistribution", Socioeconomic Review, Vol. 6 pp. 35 - 68euroepan

Laffan, B. \& O'Mahony, J. (2008) Ireland and the European Union, Palgrave Macmillan

Lyons, P. (2008) Public Opinion, Politics in Contemporary Ireland. Dublin: Irish Academic Press

Moravsik, A. (2008) “Don’t Know? Vote No!”, Prospect Magazine, July 2008

Murphy, M. C. (2018) Europe and Northern Ireland's Future: Negotiating Brexit's Unique Case Agenda Publishing

O’Brennan, J. (2019) "Requiem for a Shared Interdependent Past: Brexit \& the Deterioration in UK-Irish Relations", Capital and Class pp. 1-15

O’Mahony, J. A. (2009) "Ireland's EU Referendum Experience", Irish Political Studies, Vol. 24, No. 4, pp. 429-446

Okolikj, M. \& Quinlan, S. (2016) "Context Matters: Economic Voting in the 2009 and 2014 European Parliament Elections", Politics and Governance, Vol. 4, Issue 1

Quinlan, S. (2010) "The 2009 European Parliament Election in Ireland", Irish Political Studies, Vol. 25, No. 2, pp. 289-301

Quinlan, S. (2012) "The Lisbon Experience in Ireland: No in 2008 but Yes in 2009 - How and why", Irish Political Studies, Vol. 27, No. 1, pp. 139-153

Quinlan, S. \& Okolikj, M. (2016) “This Time it's different... but not really! The 2014 European Parliament Elections in Ireland", Irish Political Studies, Vol. 31, No. 2, pp. 300-314

Simpson, K. \& Loveless, M. (2017) "Another Chance? Concerns about Inequality, Support for the European Union and Further European Integration, Journal of European Public Policy, Vol. 24, Issue 7, pp. 1069 -1089

Simpson, K. (2018a) "What to do about Inequality? Public Opinion Support for the European Union and Further European Integration in the Republic of Ireland", Irish Political Studies

Simpson, K. (2018b) "Ireland: The Model EU Citizen? Explaining Irish Attitudes towards the European Union", Political Insight

Sinnott, R. (1995) Knowledge of the European Union in Irish Public Opinion: Sources and Implications, Institute of European Affairs (IEA), Occasional Paper No. 5 (Dublin Institute European Affairs)

Sinnott, R. (2002) “Cleavages, Parties \& Referendums: Relationships Between Representative and Direct Democracy in the Republic of Ireland", European Journal of Political Research, Vol. 41, pp. 820-824

Sinnott, R. (2005) "Uphill Task to Win EU Treaty Poll Here", The Irish Times, $14^{\text {th }}$ June 2005

Sinnott, R. \& Elkink, J., O'Rourke, K. \& McBride, J. (2010) "Attitudes and Behaviour in the Second Referendum on the Treaty of Lisbon", Report prepared for the Department of Foreign Affairs: UCD Geary Institute

Sky Data Poll (2019), Available at: https://interactive.news.sky.com/ROI TABS 0219.pdf Accessed: 17/06/19

Standard Eurobarometer Data 2009 - 2018, available at: https:/www.gesis.org/eurobarometerdata-service/survey-series/standard-special-eb/ Accessed: 17/06/19

Sunday Business Post/Red C Poll (2019), available at: https://www.businesspost.ie/politics/polling-data Accessed: 17/06/19 